\title{
Animal Performance, Feeding Behaviour and Carcass Traits of Feedlot Cattle Diet Fed With Agro-Industrial By-Product as Fat Source
}

\author{
Angelo Polizel Neto ${ }^{1}$, Roberto O. Roça ${ }^{2}$, Renata H. Branco ${ }^{3}$, Sarah M. F. Bonilha ${ }^{3}$, Ernani N. Andrade ${ }^{2}$, \\ Tatiane L. S. Corvino ${ }^{3} \&$ Helen F. B. Gomes ${ }^{1}$ \\ ${ }^{1}$ Instituto de Ciências da Saúde, Universidade Federal do Mato Grosso, Sinop, Mato Grosso, Brazil \\ ${ }^{2}$ Universidade Estadual Paulista "Júlio de Mesquita Filho", Faculdade de Ciências Agronômicas, Departamento \\ de Economia, Sociologia e Tecnologia, Botucatu, São Paulo, Brazil \\ ${ }^{3}$ Instituto de Zootecnia, Centro de Pesquisas em Pecuária de Corte, Sertãozinho, SP, Brazil \\ Correspondence: Angelo Polizel Neto, Instituto de Ciências da Saúde, Universidade Federal do Mato Grosso, \\ Avenida Alexandre Ferronato, 1200, Sinop, Mato Grosso, Brazil. E-mail: polizelneto@ufmt.br
}

\author{
Received: February 21, 2014 Accepted: March 25, 2014 Online Published: May 15, 2014 \\ doi:10.5539/jas.v6n6p54 URL: http://dx.doi.org/10.5539/jas.v6n6p54
}

\begin{abstract}
In feedlot system is particularly important to reduce the cattle feeding cost without impact on the animal gain and carcass, in this sense, aimed with this study to evaluate animal performance and carcass traits of the young Nellore male $(\mathrm{n}=40)$ finished with agro-industrial by-products in feedlot diet. The addition of cottonseed by-product (CSB) was based on the ether extract (EE) contents in the feedlot diet: 3, 4 and 5\%; and two other reference treatments were also tested, with 3 and $5 \%$ of EE content and soybean by-product (SOB) as fat source, totalling five experimental diets. In diets with $3 \% \mathrm{EE}, \mathrm{CSB}$ did not alter performance, gain cost or carcass traits compared to the SOB. In diets with $5 \% \mathrm{EE}$, animals fed with CSB showed greater dry matter (DM) intake than animals fed with SOB (10.34 versus $8.94 \mathrm{~kg} /$ day), but because CSB is a cheaper ingredient than SOB, it reduced the gain cost from 1.60 to $1.35 \mathrm{US} \$ / \mathrm{kg}$. The CBS used in diet with 3,4 and $5 \% \mathrm{EE}$ increased the daily gain $(1.17,1.38$ and 1.50 $\mathrm{kg} /$ day) and the rumination time $(225,338$ and $370 \mathrm{~min} / \mathrm{day}$, respectively). So, CSB does not change the carcass traits nor the feeding behaviour when compared to SOB. The increased of CSB concentration in the diet raised the daily gain, DM intake and rumination time, with no changes in carcass traits.
\end{abstract}

Keywords: behaviour, cottonseed by-product, fat source, gain cost

\section{Introduction}

Cattle feedlot finishing faces challenges imposed by feeding cost minimization, which is most of the costs, and the growing demand for a rational and sustainable use of natural resources. One way to achieve this cost minimization is replacing traditional grains used in the animal feeding by other protein and energy sources presenting lower cost and not competing with the ingredients used in foods for human consumption.

Millen, Pacheco, Arrigoni, Galyean, and Vasconcelos (2009) reported that $80 \%$ of the Brazilian feedlot consulting nutritionists used a by-product in their formulations for beef cattle, especially cottonseed. A similar study conducted in the United States showed that $82 \%$ of Americans nutritionists also use some by-product in their formulations, mainly corn derived from ethanol distillers (Vasconcelos \& Galyean, 2007).

Based on modifications of the process of ethanol production, Berger and Singh (2010) predicted effects in animal nutrition, bearing in mind the amount and nutritional characteristics of the new by-products. They also suggested that beef cattle can efficiently use these by-products as replacements for the traditional sources of protein and energy. Similar results were obtained by Wogar and Ayuk (2012) with grasscutter in Nigeria farms fed with low-cost agro-industrial by-products.

The extraction of oil from cottonseed aims at obtaining vegetable oil widely used in the food industry and increasingly in biodiesel production (Meneghetti et al., 2006). Winterholler, Lalman, Hudson, and Goad (2009) reported that some industries have developed mechanical techniques for cottonseed oil extraction because of high demand for cottonseed oil as a raw material for biofuel production, generating cottonseed meal extruded and pelleted as by-product, which can be used in animal feeding. 
Studies have been conducted for the feasibility of the use of cotton by-products in ruminant feeding, especially cottonseeds (Aferri, Leme, Silva, Putrino \& Pereira, 2005; Stelzleni, Froetschel, \& Pringle, 2013) cottonseed meal, (Pina et al., 2006) cottonseed hulls (Magalhães et al., 2005; Kazama et al., 2008) and cottonseed cake for dairy cows (Alves et al., 2010); and wheat offal and soybean meal to grasscutters (Wogar \& Ayuk, 2012). However, differences in dry matter (DM) intake related to fat sources using cottonseed and its by-products were also observed (Cranston et al., 2006). Furthermore Costa et al. (2011) found a linear decrease in DM intake and weight gain of cattle with increase of cottonseed levels; or Gunn, Weaver, Lemenager, Gerrard, Claeys, and Lake (2009), who found a reduction in gain of Angus cattle fed with distillery waste and soybean oil.

Thus, the objective of this study was to evaluate animal performance, feeding behaviour and carcass traits of young Nellore bulls finished in feedlots with increasing of agro-industrial by-products in the diet.

\section{Methods}

\subsection{Animal Welfare, Pens and Management}

All procedures in this trial were approved by the Ethics Committee of Animal Experimentation of UNESP "Julio de Mesquita Filho", Campus of Botucatu - Sao Paulo, Brazil (48/2008-CEEA).

The experiment was carried out in the Advanced Center of Technological Research of Beef Cattle Agribusiness, a sector in the Institute of Animal Science, linked to the Agriculture and Supply Secretary of São Paulo State, located in Sertaozinho, Sao Paulo, Brazil, latitude $21^{\circ} 10^{\prime} \mathrm{S}$ and longitude $48^{\circ} 05^{\prime} \mathrm{W}$. This region has humid tropical climate, with annual average temperature of $24^{\circ} \mathrm{C}$ and annual average rainfall of $1,300 \mathrm{~mm}$.

Forty $20 \pm 2$ month-old Nellore bulls were assigned to eight different plots according to their initial body weight (BW) $(313.8 \pm 41.2 \mathrm{~kg})$ before their adaptation to diets.

The animals were housed in individual pens, so that each animal was considered an experimental unit. Their adaptation to diets and pens lasted 22 days, and they were evaluated during a 102 days experimental period. The 10 $\mathrm{m}^{2}$ area pens were partially covered and had concrete floor, with an individual 1.5 meter linear trough and a 100 litre Australian water trough between every two pens.

The animals were individually identified by a tattoo on the left ear, treated against endoparasites and ectoparasites, and vaccinated against clostridiosis (Clostridium sp; Ourovac ${ }^{\mathbb{B}}$ Clostridium; Ourofino, Cravinhos, Brazil) and foot-and-mouth disease.

\subsection{Treatments}

The two agro-industrial by-products used were cottonseed by-product (CSB) and soybean by-product (SOB), and the feedlot diets were formulated according to the nutritional demands estimated by CNCPS v. 6.1 - Cornell Net Carbohydrate and Protein System (Fox, Sniffen, O'Connor, Russell, \& Van Soest, 1992)

The addition of CSB was based on the ether extract (EE) contents in the feedlot diet: 3, 4 and 5\%. Two other reference treatments were also tested, namely 3 and $5 \%$ of EE content and SOB as fat source, totalling five experimental diets, presented in Table 1 and abbreviated as:

$3 \mathrm{SOB}=3 \%$ of ether extract in the diet with fat source from soybean by-product;

$5 \mathrm{SOB}=5 \%$ of ether extract in the diet with fat source from soybean by-product;

$3 \mathrm{CSB}=3 \%$ of ether extract in the diet with fat source from cottonseed by-product;

$4 \mathrm{CSB}=4 \%$ of ether extract in the diet with fat source from cottonseed by-product;

$5 \mathrm{CSB}=5 \%$ of ether extract in the diet with fat source from cottonseed by-product.

The CSB utilized, provided by Bunge Alimentos Ltda, and is the resulting by-product of the physical extraction of semi-delinted cottonseed oil, similar to the by-product described by Winterholler et al. (2009). In the SOB diets, acidic soybean dreg was used as fat source, which is a residual by-product of the refining process of commercial soybean oil.

Protein diet values were extrapolated so that they provided greater CSB inclusion, and, therefore, the diets were formulated with contents close to $18 \% \mathrm{CP}$, keeping the concentrate: roughage ratio close to $80: 20$, including $31.5 \%$ of corn. In diets with the same EE content, similar amounts of urea and molasses were used.

The ration was provided as total diet, twice a day, at 08:00 and 16:00, in amounts that allowed leftovers between 5 and $10 \%$ of the observed DM voluntary intake, as a way to allow animals to express the consumption. 
Table 1. Composition of diets provided to feedlot animals $(\% \mathrm{DM})$

\begin{tabular}{|c|c|c|c|c|c|}
\hline \multirow{2}{*}{ Ingredients } & \multicolumn{5}{|c|}{ Diets $^{+}$} \\
\hline & $3 \mathrm{SOB}$ & $5 \mathrm{SOB}$ & $3 \mathrm{CSB}$ & 4CSB & $5 \mathrm{CSB}$ \\
\hline Brachiaria sp hay & 19.5 & 19.9 & 19.5 & 19.4 & 19.4 \\
\hline Ground corn & 31.2 & 31.9 & 31.2 & 31.1 & 31.1 \\
\hline Ground sorghum & 35.2 & 14.7 & 33.02 & 19.31 & 5.52 \\
\hline Soybean meal (46\% CP) & 5.84 & 24.1 & - & - & - \\
\hline Soybean by-product (SOB) & 1.66 & 7.43 & - & - & - \\
\hline Cottonseed by-product $(\mathrm{CSB})^{++}$ & - & - & 9.77 & 26.1 & 42.2 \\
\hline Molasses & 2.63 & 0.34 & 2.63 & 1.55 & 0.33 \\
\hline Urea & 2.65 & 0.32 & 2.67 & 1.47 & 0.31 \\
\hline Mineral supplement ${ }^{+++}$ & 1.10 & 1.10 & 1.10 & 1.10 & 1.10 \\
\hline Feed cost (U\$ kg-1 dry matter) & 0.212 & 0.261 & 0.196 & 0.195 & 0.193 \\
\hline \multicolumn{6}{|c|}{ Chemical Analysis } \\
\hline Total digestible nutrients & 66.1 & 68.7 & 64.2 & 64.4 & 64.5 \\
\hline Metabolizable energy (Mcal/kg) & 2.39 & 2.43 & 2.32 & 2.33 & 2.34 \\
\hline Crude protein & 17.9 & 18.9 & 17.7 & 18.6 & 19.4 \\
\hline Ether extract & 3.07 & 5.00 & 3.01 & 3.86 & 4.79 \\
\hline Neutral detergent fiber & 40.6 & 40.1 & 45.8 & 45.2 & 49.1 \\
\hline Lignin & 2.07 & 3.34 & 2.26 & 4.00 & 5.57 \\
\hline
\end{tabular}

${ }^{+} 3 \mathrm{SOB}$ and $5 \mathrm{SOB}=$ diets with 3 and $5 \%$ ether extract and soybean by-product as lipid source; 3CSB, 4CSB and $5 \mathrm{CSB}=$ diets with 3, 4 and 5\% ether extract and cottonseed by-product as lipid source, respectively.

${ }^{++}$CSB composition: 91.2\% DM; 9.33\% EE; 28.5\% CP; 51.7\% NDF; 31.9\% ADF; gossypol content was under the minimum limit of analytical quantification $(5 \mathrm{mg} / \mathrm{kg}$ ). SOB composition: $56.3 \% \mathrm{DM}$ and $38.4 \%$ of EE.

${ }^{+++}$Composition of the mineral supplement (amount/kg): 180 g Ca; 90 g P; 10 g Mg, 13 g S; 93 g Na; 145 g Cl; 17 mg Se; 1000 mg Cu; 826 mg Fe; 4000 mg Zn; 1500 mg Mn; 150 mg I; 80 mg Co; 900 mg Fl; 38.7 ppm Monensine.

\subsection{Performance}

The adaptation period lasted 22 days, with the initial supply of diets around $2.3 \% \mathrm{BW}$, and following the protocol of sequential reduction in roughage:concentrate ratio: 5 days with 50:50; 5 days with 40:60; 5 days with 30:70 and 7 days with 20:80. At the end of the adaptation period the animals were re-weighed, and this weight was considered as the weight at the onset of the experiment (initial BW). The animals were weighed in subperiods: after 28, 56, 84 and 102 days from the beginning of the experiment; all weighing were made a 14 hours solid fasting with free access all time to water.

Daily were weighed the diet offered and the leftovers to determination of feed intake. Representative samples of diets and leftovers for individual animals were collected weekly, forming a composite sample of each diet and other individual leftovers in each subperiod. Diets and leftovers were dried in a forced-air ventilation oven $55 \pm$ $5^{\circ} \mathrm{C}$ to constant weight and they were ground in a Stationary Mill type Willey, using $1 \mathrm{~mm}$ sieves. The dry matter (item 934.01), ether extract (item 920.39), crude proteins by the micro-Kjeldahl method (item 954.01) were determined according to Association Official Analysis Chemistry (2007). The levels of lignin, acid and neutral detergent fiber were measured according to Van Soest, Robertson and Lewis (1991).

\subsection{Feeding Behaviour}

Feeding behaviour was observed for 3 days at random on days $49^{\text {th }}, 65^{\text {th }}$ and $96^{\text {th }}$, during an uninterrupted period of 24 hours, in 10-minute intervals, through direct and individual observation, with previous adaptation of the animals, to determine the time spent in feeding and rumination, as well as the time in which the animal remained lying. During the night observation, the environment was maintained with artificial illumination, also with previous adaptation of the animals. 
Feeding and rumination times were adjusted to the average DM intake observed on two consecutive days: the day before and the day of behaviour observation. This procedure was performed to adjust the feeding time to intake, because the beginning of the observation did not always coincide with the exact time at which the diet was served to the animals, and the time spent on rumination also reflected the intake of the previous day.

\subsection{Slaughter and Carcass Evaluation}

The animals were slaughtered at Frigonobre Slaughterhouse in Torrinha, SP, Brazil, $204 \mathrm{~km}$ from the experiment location. All animals were slaughtered in a single day in the same lot. At exsanguination, the animals were identified by their tattoos and numbered in ordinal order according to their entrance. The animals were stunned by a pneumatic hammer, and immediately after the procedures of exsanguination, skinning, evisceration and carcass preparation for chilling were done.

At evisceration, the liver and kidney, pelvic and heart fat (KPH) were collected and weighed. After the cooling period $\left(24\right.$ hours at $\left.7^{\circ} \mathrm{C}\right)$, the beef carcass side was re-weighed to obtain the cold carcass weight. Next, the internal length of half carcasses, the distance between the cranial extremity of the iliac tuberosity and the cranial border of the first rib were all measured.

The half carcasses were divided into three primary cuts: forequarter, composed of the cranial portion of the cross section between the $5^{\text {th }}$ and $6^{\text {th }}$ ribs; spare ribs, composed of the latero-ventral part of the abdomen and the $6^{\text {th }}$ to $13^{\text {th }}$ ribs, dorsally sectioned at $\pm 20 \mathrm{~cm}$ from the midline of the half-carcass, and the hindquarter, comprised by the full leg and all loin from the $6^{\text {th }}$ rib.

The Musculus longissimus (LM), as well as its bone base was sectioned between the $12^{\text {th }}$ and $13^{\text {th }}$ ribs to enable the measurement of both the subcutaneous fat thickness, with the aid of digital callipers, and the LM area, by vegetal paper tracing, for further evaluation on a digital table with planimetry system, in the Laboratory of Remote Sensing in the Department of Rural Engineering - FCA, UNESP - Botucatu.

The proportion of the whole carcass meat cuts was calculated by the equation proposed by Cross, Carpenter \& Smith (1973), currently accepted by the United States Department of Agriculture:

$$
\text { Cutability }=51.34-2.277 \times \mathrm{SBF}-0.462 \times \mathrm{KPH}+0.1147 \times \text { LMarea }-0.0205 \times \mathrm{HCW}
$$

where: $\mathrm{SBF}=$ subcutaneous fat thickness $(\mathrm{cm}) ; \mathrm{KPH}=$ kidney, pelvic and heart fat (percentage of HCW); LMarea = M. longissimus area $\left(\mathrm{cm}^{2}\right) ; \mathrm{HCW}=$ hot carcass weight $(\mathrm{kg})$.

\subsection{Statistical Analysis}

Data on final BW, feeding behaviour and carcass traits were evaluated with animal (random), diet and plot effects (fixed) with initial BW as co-variable; data on performance, nutrients and DM intake were added sub-period experimental effect as repeated measures.

Means were tested by four contrasts, the first two aimed to analyse if, for the same dietary EE content, CSB differed from SOB: $\mathrm{C} 1=3 \mathrm{SOB}$ versus $3 \mathrm{CSB}$ and $\mathrm{C} 2=5 \mathrm{SOB}$ versus $5 \mathrm{CSB}$; the other two contrasts $(\mathrm{C} 3$ and $\mathrm{C} 4)$ aimed to evaluate the linear and quadratic effect of CSB inclusion.

All data were analysed using PROC MIXED by Statistical Analysis System Version 9.0 (SAS, 2002) and the contrasts were tested by Scheffe's test, considering the difference to be significant when $P<0.05$. Moreover, when significant at $\mathrm{C} 3$ and/or C4 the CSB increase was evaluated by PROC REG.

\section{Results and Discussion}

\subsection{Performance}

The fat sources, SOB or CSB at 3 and $5 \%$ of EE in the diet, did not affect $(\mathrm{P} \geq 0.05)$ the final BW and the daily gain (Table 2; C1 and C2, respectively), which is in agreement with Lofgreen (1965) that studied cattle fed residual oil from restaurants and cottonseed, with Zinn (1989a) who compared combinations of restaurant waste oil, animal fat and vegetable in the diet of feedlot cattle, with Cranston et al. (2006) who provided the feedlot cattle diets with cottonseed and cottonseed by-products, and all studies did not find difference in beef cattle weight gain. In addition, this finding was similar to that of Stelzleni et al. (2013), who found no change in performance and DM intake in heifers supplemented with full-fat extruded cottonseed pellets. 
Table 2. Estimated means of performance, intake and gain of Nellore cattle fed with agro-industrial by-products

\begin{tabular}{|c|c|c|c|c|c|c|c|c|c|c|c|c|}
\hline \multirow{2}{*}{ Component } & \multirow{2}{*}{ Means } & \multicolumn{5}{|c|}{ Treatments $^{+}$} & \multirow{2}{*}{$\mathrm{SEM}^{++}$} & \multicolumn{5}{|c|}{$P^{+++}$} \\
\hline & & $3 \mathrm{SOB}$ & $5 \mathrm{SOB}$ & $3 \mathrm{CSB}$ & $4 \mathrm{CSB}$ & $5 \mathrm{CSB}$ & & Model & $\mathrm{C} 1$ & $\mathrm{C} 2$ & $\mathrm{C} 3$ & $\mathrm{C} 4$ \\
\hline Initial BW (kg) & 314 & 309 & 319 & 308 & 313 & 319 & 6.32 & 0.01 & - & - & - & - \\
\hline Final BW (kg) & 452 & 440 & 464 & 433 & 454 & 467 & 7.65 & 0.03 & 0.57 & 0.83 & $0.02^{(2)}$ & 0.69 \\
\hline Daily gain(kg/day) & 1.35 & 1.24 & 1.47 & 1.17 & 1.38 & 1.50 & 0.10 & 0.03 & 0.57 & 0.83 & $0.02^{(3)}$ & 0.69 \\
\hline DM intake(kg/day) & 9.20 & 8.43 & 8.94 & 8.34 & 9.90 & 10.3 & 0.23 & 0.01 & 0.89 & 0.04 & $0.01^{(4)}$ & 0.36 \\
\hline DM/BW (\%) & 2.41 & 2.27 & 2.30 & 2.24 & 2.58 & 2.65 & 0.05 & 0.01 & 0.85 & 0.02 & $0.02^{(5)}$ & 0.29 \\
\hline Gain:Feed (g/kg) & 161 & 162 & 179 & 154 & 154 & 157 & 0.01 & 0.03 & 0.31 & 0.01 & 0.42 & 0.78 \\
\hline $\begin{array}{l}\text { Gain } \text { Cost }^{++++} \text {(US\$ } / \mathrm{kg} \\
\text { gain) }\end{array}$ & 1.45 & 1.45 & 1.60 & 1.46 & 1.41 & 1.35 & 0.10 & 0.04 & 0.98 & 0.03 & 0.14 & 0.92 \\
\hline
\end{tabular}

\begin{tabular}{lccccccccccccc}
\hline & \multicolumn{11}{c}{ Nutrients Daily Intake } \\
\hline CP intake (kg/day) & 1.56 & 1.40 & 1.56 & 1.29 & 1.68 & 1.85 & 0.05 & 0.00 & 0.32 & 0.02 & $0.00^{(6)}$ & 0.25 \\
CP intake/BW (\%) & 0.41 & 0.38 & 0.40 & 0.35 & 0.44 & 0.47 & 0.01 & 0.00 & 0.21 & 0.01 & $0.00^{(7)}$ & 0.17 \\
EE intake (kg/day) & 0.31 & 0.26 & 0.36 & 0.24 & 0.34 & 0.37 & 0.01 & 0.00 & 0.34 & 0.88 & $0.00^{(8)}$ & 0.06 \\
EE intake/BW (\%) & 0.08 & 0.07 & 0.09 & 0.06 & 0.09 & 0.09 & 0.002 & 0.00 & 0.16 & 0.93 & $0.00^{(9)}$ & 0.02 \\
NDF intake (kg/day) & 6.31 & 6.62 & 5.81 & 6.83 & 6.40 & 5.81 & 0.11 & 0.01 & 0.47 & 0.99 & 0.12 & 0.94 \\
NDF intake/BW (\%) & 1.66 & 1.78 & 1.50 & 1.84 & 1.67 & 1.50 & 0.02 & 0.02 & 0.35 & 0.97 & 0.08 & 0.93
\end{tabular}

${ }^{+} 3 \mathrm{SOB}$ and $5 \mathrm{SOB}=$ diets with 3 and $5 \%$ ether extract and soybean by-product as lipid source; 3CSB, 4CSB and $5 \mathrm{CSB}=$ diets with 3, 4 and 5\% ether extract and cottonseed by-product as lipid source, respectively.

${ }^{++} \mathrm{SEM}=$ standard error of the mean, $\mathrm{n}=40$.

${ }^{+++} \mathrm{C} 1=3 \mathrm{SOB}$ vs $3 \mathrm{CSB}, \mathrm{C} 2=5 \mathrm{SOB}$ vs $5 \mathrm{CSB}, \mathrm{C} 3=$ linear effect of CBS inclusion, $\mathrm{C} 4$ = quadratic effect of CBS inclusion, contrasts tested by Scheffé's test.

${ }^{++++}$Gain Cost, calculated by equation $=[($Dry Matter Intake $x$ Diet Costs $) /$ Daily Gain $]$

$\mathrm{BW}=$ body weight $\mathrm{DM}=$ dry matter; $\mathrm{CP}=$ crude protein; $\mathrm{EE}=$ ether extract; $\mathrm{NDF}=$ fiber in neuter detergent

Final $\mathrm{BW}=79.53+1.07 \mathrm{x}$ Initial $\mathrm{BW}+9.13 \times \mathrm{EE}$ of the diet with $\mathrm{CSB}\left(\mathrm{R}^{2}=0.69 ; P<0.001\right)$

Daily gain $=0.99+0.093 \times$ EE of the diet with $\mathrm{CSB}\left(\mathrm{R}^{2}=0.07 ; P=0.22\right)$

$\mathrm{DM}$ intake $=1.65+0.018 \times$ Initial $\mathrm{BW}+0.534 \mathrm{xEE}$ of the diet with $\mathrm{CSB}\left(\mathrm{R}^{2}=0.30 ; P=0.03\right)$

$\mathrm{DM}$ intake/ $\mathrm{BW}=2.09+0.1 \times \mathrm{EE}$ of the diet with $\mathrm{CSB}\left(\mathrm{R}^{2}=0.07 ; P=0.21\right)$

$\mathrm{CP}$ intake $=-0.26+0.003 \times$ Initial $\mathrm{BW}+0.21 \times \mathrm{EE}$ of the diet with $\mathrm{CSB}\left(\mathrm{R}^{2}=0.53 ; P<0.001\right)$

$\mathrm{CP}$ intake/BW $=0.28-2.1 \times 10^{-4} \times$ Initial $\mathrm{BW}+0.05 \times \mathrm{EE}$ of the diet with $\mathrm{CSB}\left(\mathrm{R}^{2}=0.42 ; P=0.002\right)$

$\mathrm{EE}$ intake $=-0.07+6.4 \times 10^{-4} \times$ Initial $\mathrm{BW}+0.046 \mathrm{xE}$ of the diet with $\mathrm{CSB}\left(\mathrm{R}^{2}=0.51 ; P<0.001\right)$

$\mathrm{EE}$ intake/BW $=0.038+0.01 \times \mathrm{EE}$ of the diet with $\mathrm{CSB}\left(\mathrm{R}^{2}=0.40 ; P<0.001\right)$

However, the CSB increase in the diet changed $(P<0.05)$ the final BW and daily gain, in that animals showed 1.17 $\pm 0.14 \mathrm{~kg} /$ day of the gain when CSB was used $3 \%$ EE diet and $1.50 \pm 0.19 \mathrm{~kg} /$ days in $5 \%$ EE diet, which is an increase superior to $28 \%$. An opposite finding was reported by Gunn, Weaver, Lemenager, Gerrard, Claeys, and Lake (2009), who found a reduction in gain of Angus cattle with increase the diet EE, using distillery waste and soybean oil as fat source.

The difference in $\mathrm{C} 3$ for final $\mathrm{BW}$ and the non-significance in $\mathrm{C} 4$ for the same variable indicates that the mean in the intermediate level of CSB inclusion is not different $(P \geq 0.05)$ from the mean of the extreme levels, indicating a linear relationship between the final live weight with increasing inclusion of CSB, confirmed by the multiple linear regression [equation 2], in which the final BW of $433 \pm 20,454 \pm 16$ and $467 \pm 16 \mathrm{~kg}$ were found for an increase of 3, 4 and $5 \%$ of EE dietary content with CSB as source. 
Despite the significant contrasts that were detected for daily gain, as well as for the final BW, the daily weight gain data did not fit the proposed linear equation $(P=0.22)$ [Equation 3]. Therefore, the linearity of the gain as a function of the increasing content of CSB in the diet cannot be stated. A similar conclusion was reported by Vander Pol, Luebbe, Crawford, Erickson, and Klopfenstein (2009) who provided confined cattle with corn by-product from distillers in increasing levels of EE dietary $(4,6.4$ and 8.8\%) and found no changes in animal performance.

The ratio of DM intake by BW was $2.41 \pm 0.05$, which was close to the value of $2.55 \%$ found by Machado Neto et al. (2010), for Nellore finished in feedlot. Ítavo, Valadares Filho, Silva, Valadares, and Cecon (2002), when studying Nellore fed with different levels of dietary protein, found the proportion of $2.21 \%$ for diets with levels $18 \%$ of protein. However, the average DM intake found in this study was substantially higher than the mean value of $1.9 \%$ shown by Messana, Berchielli and Arcuri (2010) with cannulated Nellore animals fed 80\% DM of cottonseed processed residue. In addition, those authors found that intake might have been affected by the high lignin amount in the fibrous portion of that dietary ingredient.

In $3 \% \mathrm{EE}$ diets, the use of fat sources did not affect $(P=0.89)$ the DM intake of animals, which were found to be $8.43 \pm 0.49$ and $8.34 \pm 0.56 \mathrm{~kg}$ for SOB and CSB, respectively. However, in the 5\% EE diets, a greater DM intake was found, in $\mathrm{kg} / \mathrm{day}(P=0.04)$ and proportion to BW $(P=0.02)$. Animals had a $1.42 \mathrm{~kg}$ greater of DM intake for the CSB diet, which significantly reduced feed efficiency of $179 \pm 0.01 \mathrm{~g} / \mathrm{kg}$ for $5 \mathrm{SOB}$ to $157 \pm 0.01 \mathrm{~g} / \mathrm{kg}$ for $5 \mathrm{CSB}$. This means that even in the diets with $42 \%$ of CSB (5CSB diet; Table 1) DM intake was not affected by the inclusion of this by-product, as reported in Messana et al. (2010).

The occurrence of increased DM intake and reduced feed efficiency with the use of CSB can be attributed to the lower energy intake of this ingredient (Table 1), which has possibly been compensated by a greater intake by the animals, because the energy density of the diet is an important intake regulatory factor (Zinn, 1989a). This interpretation is corroborated by the study of Galyean and Defoor (2003), who stated that bovine fed diets with lower energy might raise intake to achieve the same energy level as long as the intake is not limited by the filling of the digestive tract. Differences in DM intake related to fat sources were also observed by Cranston et al. (2006), using cottonseed and its by-products, and the same authors reported that the increase in DM intake in diets with cottonseed and its by-products may be the effect of greater fiber and lower energy concentration of these diets.

Regarding the dietary volume effect of CSB, a by-product that presents a large amount of cottonseed hulls, the data from this study are partly consistent with the studies of Chizzotti et al. (2005), who observed that cottonseed hulls increased the DM intake without changing the weight gain. Moore, Poorem, and Swingle (1990) found that animals that consumed cottonseed hulls instead of alfalfa hay had greater homogeneity of the diet in the rumen and ruminal escape probably was greater and therefore DM intake was stimulated.

However, the greater DM intake of animals consuming CSB did not avoid the use of this by-product in the diets with greater EE content. CBS is considered a cheap ingredient [on April, 2009, the price of the ingredient was US\$ 372.64 and US\$ 150.52 (considering US\$1.00=R $\$ 0.4589$ ) respectively for each ton of DM of soybean meal and CSB]. The use of CSB reduced the cost of the diet (Table 1) and thereby reduced the cost of gain, even with greater DM intake: $1.60 \mathrm{US} \$ / \mathrm{kg}$ of gain with the use of SOB and $1.35 \mathrm{US} \$ / \mathrm{kg}$ of gain with CSB, in diets containing $5 \% \mathrm{EE}$.

As it was found a difference in DM intake in the fat sources, the increasing levels of inclusion of CSB increased linearly $(P=0.03)$ [equation 4] the DM intake, $8.34 \pm 0.56,9.90 \pm 0.38$ and $10.34 \pm 0.43 \mathrm{~kg} /$ day of DM for diets with 3, 4 and 5\% EE, respectively, and CSB as fat source. Zinn (1989a) working with feedlot, found that a fat content of 2, 5.5 and 9\%EE in the diet did not affect DM intake of Brahman crossbreed animals, which is not in agreement with this study.

Felton and Kerley (2004a) first observed a positive linear effect on DM intake of young crossed steers as a function of dietary EE content in 52 days of experiment with diets ranging from 4.5 to $10 \% \mathrm{EE}$, using soybean as fat source. Nevertheless, the same authors, in a second 72-day experiment, found no effect of increasing the EE content in diets on DM intake of animals. Vander Pol et al. (2009) in two reported experiments with diets ranging from 3.5 to $8.8 \% \mathrm{EE}$ also found no effect on DM intake of animals.

Contrary to the previous studies, Costa et al. (2011) found a linear decrease in DM intake of cattle as levels of cottonseed were increased, and justified this reduction as an effect of the reduction in fiber digestibility and the increase in rumen retention time of ingestion caused by greater amount of EE in the diet. Interestingly, the same authors found that this effect occurred in diets with levels of EE above 5\%, and, in this experiment, $5 \%$ was the maximum threshold used. 
An influence $(P<0.05)$ of fat sources and increasing levels of CSB was found for protein intake (Table 2). In $3 \%$ EE diets, the fat sources did not influence $(P \geq 0.05)$ the protein intake, absolute and relative to BW; however, greater protein intake $(P<0.05)$ was found in the $5 \% \mathrm{EE}$ diet and CSB. This increase in protein intake is due to the greater DM intake and the diet protein content (Table 1).

The non-significance $(P \geq 0.05)$ of the contrasts that compared the neutral detergent fiber (NDF) intake of as a function of the fat sources $(\mathrm{C} 1$ and $\mathrm{C} 2)$ was contrary to what was expected, especially in 5CSB, which presented greater DM intake and it also presented a numerically greater content of NDF than the diet with SOB (Table 1). Mathematically, a greater NDF intake was expected, but did not occur due to the selectivity trait of the animal, which avoided the intake of more voluminous ingredients.

Based on data from all cattle categories, Detmann et al. (2003) reported the reduction in DM intake due to the increase in the amount of NDF in the diet. The same authors also found that the peak NDF intake $[2.95 \% \mathrm{BW}]$ in tropical conditions was with $40.4 \% \mathrm{DM}$ of NDF in the diet. A difference $(P<0.05)$ between extreme levels of CSB inclusion was found in the nutrient intake, with a positive linear relationship $(P<0.02)$ [equations 6 to 9 ] with CBS inclusion to protein and EE intake, due to the linear increase in DM intake [Equation 4] which increased the ingestion of these nutrients. However, NDF intake was not changed with increasing CSB levels, as the means achieved for the NDF intake proportional to BW were $1.84 \pm 0.5,1.67 \pm 0.03$ and $1.50 \pm 0.08 \%$ for $3 \mathrm{CSB}, 4 \mathrm{CSB}$ and $5 \mathrm{CSB}$, respectively.

The overall mean NDF intake, related to BW, was $1.66 \pm 0.02 \%$; Detmann et al. (2003) reported a NDF intake of $1.12 \%$, with a range from 0.03 to $2.21 \%$, regarding animals of various categories and an average NDF content of $48.4 \% \mathrm{DM}$ in the diets. Ítavo et al. (2002) found an average NDF intake of $0.99 \% \mathrm{BW}$ for Nellore cattle at age and weight similar to those used in this experiment, using diets with $18 \% \mathrm{DM}$ of protein. Compared to the previous studies, the increase in the relative NDF intake here reported is due to the use of CBS, which, despite being included in the diet as fat source, it is also an ingredient rich in fiber and protein.

\subsection{Feeding Behaviour}

Regarding the values related to the ingestive behaviour of the animals (Table 3$)$, no influence $(P \geq 0.05)$ of the fat source and CSB inclusion at feeding time was observed, but an effect of increasing inclusion $(P<0.001)$ of CSB in the rumination time of the animals in feedlot was found. The DM intake in the behaviour observation days did not follow the pattern of over the experiment, whereas, on the behaviour observation days, a greater DM intake was found with the use of CSB $(P<0.05)$ in the diets with $5 \% \mathrm{EE}$, like the all experiment; however, there was no difference $(P \geq 0.05)$ of DM intake with the inclusion of CSB, as it occurred with the analysis of data of the entire experiment (Table 2).

Fat sources (SOB and CSB, at 3 and $5 \%$ of EE in the diet) and the CSB increasing levels did not change $(P \geq 0.05)$ the feeding time, absolute and relative to the DM intake. A greater feeding was expected with the greater DM intake in diets with 5\% EE and CSB as fat source; however, such difference was not observed, demonstrating good acceptance of CSB by animals. The rumination time was also not affected by the CSB $(P \geq 0.05)$ compared to SOB at 3 and $5 \%$ of EE in the diet; however, the CSB addition in the diet increased linearly $(P<0.001)$ [equation 10 and 11] the rumination time. Considering that an increase in the physically effective NDF in the diet increases the time spent in rumination in dairy cows, as observed by Beauchemin and Yang (2005), together with the information that the CSB increase did not change the NDF intake (Table 3), the physical effectiveness of the NDF of this by-product was demonstrated by the positive relationship between rumination time and content of physically effective NDF (Beauchemin \& Yang, 2005). 
Table 3. Feeding behaviour of Nellore cattle fed with agro-industrial by-products

\begin{tabular}{|c|c|c|c|c|c|c|c|c|c|c|c|c|}
\hline \multirow{2}{*}{ Component } & \multirow{2}{*}{ Means } & \multicolumn{5}{|c|}{ Treatments $^{+}$} & \multirow{2}{*}{ - SEM $^{++}$} & \multicolumn{5}{|c|}{$P^{+++}$} \\
\hline & & $3 \mathrm{SOB}$ & $5 \mathrm{SOB}$ & $3 \mathrm{CSB}$ & $4 \mathrm{CSB}$ & $\overline{5 \mathrm{CSB}}$ & & Model & $\mathrm{C} 1$ & $\mathrm{C} 2$ & $\mathrm{C} 3$ & $\mathrm{C} 4$ \\
\hline DM intake (kg/day) & 827 & 7.84 & 7.49 & 8.12 & 8.80 & 8.89 & 0.30 & 0.02 & 0.73 & 0.04 & 0.34 & 0.66 \\
\hline Feeding time (min/day) & 04 & 156 & 155 & 180 & 164 & 171 & 7.60 & 0.00 & 0.17 & 0.32 & 0.59 & 0.41 \\
\hline $\begin{array}{l}\text { Feeding tir } \\
(\mathrm{min} / \mathrm{kg})\end{array}$ & 20.8 & 21.1 & 20.3 & 25.1 & 19.0 & 19.5 & 1.53 & 0.06 & 0.19 & 0.79 & 0.07 & 0.18 \\
\hline Rumination time (min/day) & 298 & 267 & 287 & 225 & 338 & 370 & 14.0 & 0.00 & 0.21 & 0.12 & $0.00^{(10)}$ & 0.17 \\
\hline $\begin{array}{l}\text { Rumination time /DM intake } \\
(\mathrm{min} / \mathrm{kg})\end{array}$ & 37.1 & 33.9 & 38.9 & 31.1 & 36.6 & 42.7 & 2.06 & 0.02 & 0.46 & 0.26 & $0.00^{(11)}$ & 0.91 \\
\hline Lying time (min/day) & 897 & 893 & 929 & 881 & 897 & 884 & 10.7 & 0.08 & 0.68 & 0.13 & 0.92 & 0.57 \\
\hline
\end{tabular}

${ }^{+} 3 \mathrm{SOB}$ and $5 \mathrm{SOB}=$ diets with 3 and $5 \%$ ether extract and soybean by-product as lipid source; 3CSB, 4CSB and $5 \mathrm{CSB}=$ diets with 3, 4 and 5\% ether extract and cottonseed by-product as lipid source, respectively.

${ }^{+} \mathrm{SEM}=$ standard error of the mean, consider $\mathrm{n}=40$.

${ }^{+++} \mathrm{C} 1=3 \mathrm{SOB}$ vs $3 \mathrm{CSB}$; $\mathrm{C} 2=5 \mathrm{SOB}$ vs $5 \mathrm{CSB}$; $\mathrm{C} 3=$ linear effect of $\mathrm{CBS}$ inclusion; $\mathrm{C} 4=$ quadratic effect of $\mathrm{CBS}$ inclusion, contrasts tested by Scheffé's test.

$\mathrm{DM}=$ dry matter.

$$
\begin{aligned}
& \text { Rumination Time }=21.11+72.5 \times \text { EE of the diet with } \mathrm{CSB}\left(\mathrm{R}^{2}=0.47 ; P<0.001\right) \\
& \text { Rumination Time/DM intake }=13.77+5.79 \times \mathrm{EE} \text { of the diet with } \mathrm{CSB}\left(\mathrm{R}^{2}=0.30 ; P<0.001\right)
\end{aligned}
$$

Another explanation for the increase in rumination time may be due to the greater intake of EE by animals, which probably caused a decrease in apparent digestibility of fiber, which is one of the factors responsible for stimulating rumination, as noted by Zinn (1989b). However, provided that it does not reduce animal performance (Table 2) and does not impair carcass traits (Table 4), this apparent reduction of fiber digestibility can be seen as an advantage in using more concentrated diets. Beauchemin and Yang (2005) reported that increase the rumination time, due to physical effectiveness of the fibre and subsequent buffering of rumen $\mathrm{pH}$, therefore avoiding clinical and subclinical acidosis and allowing the inclusion of a greater proportion of concentrated ingredients, with a proportional reduction of roughage ingredients.

\subsection{Carcass Evaluation}

The fat sources used, CSB and SOB at 3 and $5 \%$ of EE in the diet, did not affect $(P \geq 0.05)$ the carcass traits of the animals (Table 4), which is in agreement with Zinn (1989a), Felton and Kerley (2004b), Cranston et al. (2006), Larraín, Schaefer, Arp, Claus, and Reed (2009),Vander Pol et al. (2009), who also found no changes in carcass traits using different fat sources in diets for feedlot cattle.

The extreme levels of CSB changed $(P<0.05) \mathrm{KPH}$, in $\mathrm{kg}$, but the data did not fit a linear regression equation $(P$ $=0.08)$ [Equation 12] and the effect became non-significant $(P \geq 0.05)$ when the data were corrected for hot carcass weight $(\mathrm{HCW})$.

The amount of forequarter was found to be greater $(P=0.02)$ in the treatment with 5CSB than in the 3CSB (C3) treatment, with a positive linear relationship $(P=0.01)$ [Equation 13] as CSB was increased in the diet, but no differences were found when the forequarter was expressed in proportion to the cold carcass weight. Thus, the increasing inclusion of CSB in the diet did not affect carcass traits, which is similar to the observations of Felton and Kerley (2004a), who found no changes in the carcass of animals fed increasing levels of soybean.

The overall mean of KPH in relation to HCW in this study was greater than the one found by Cranston et al. (2006) ( 2.33 versus $4.68 \pm 0.13 \%$ ); however, the animals in this study showed a lower mean of HCW than the animals studied by Cranston et al. (2006) (362.2 versus $250.4 \pm 4.74 \mathrm{~kg}$ ). The average value of KPH was also greater than that observed by Bonilha et al. (2008), in summarized data of eight progenies of Nellore animals of the same pedigree of those used in this study; they found KPH of $7.62 \mathrm{~kg}$, and HCW of $277.5 \mathrm{~kg}$, with a percentage ratio of 2.74\%. In addition, Larraín et al. (2009) found a mean of KPH of 3.64\% in Angus with average HCW of $354 \mathrm{~kg}$. 
Table 4. Estimated means of carcass traits of Nellore cattle fed with agro-industrial by-products

\begin{tabular}{|c|c|c|c|c|c|c|c|c|c|c|c|c|}
\hline \multirow{2}{*}{ Component } & \multirow{2}{*}{ Means } & \multicolumn{5}{|c|}{ Treatments $^{+}$} & \multirow{2}{*}{ - $\mathrm{SEM}^{++}$} & \multicolumn{5}{|c|}{$P^{+++}$} \\
\hline & & $3 \mathrm{SOB}$ & 5SOB & $3 \mathrm{CSB}$ & $4 \mathrm{CSB}$ & $5 \mathrm{CSB}$ & & Model & $\mathrm{C} 1$ & $\mathrm{C} 2$ & $\mathrm{C} 3$ & $\mathrm{C} 4$ \\
\hline HCW (kg) & 250 & 245 & 257 & 239 & 254 & 256 & 4.74 & 0.23 & 0.49 & 0.84 & 0.09 & 0.36 \\
\hline g) & 47 & 243 & 254 & 236 & 251 & 253 & 4.69 & 0.24 & 0.44 & 0.87 & 0.09 & 0.38 \\
\hline $\mathrm{HCW} /$ & & 55.7 & 55.8 & 55.2 & 55.6 & 54.7 & & 0.54 & 0.45 & 0.13 & 0.55 & 0.30 \\
\hline & & 126 & 125 & 124 & 124 & 125 & & 0.52 & 0.56 & 0.99 & 0.67 & 0.54 \\
\hline & 08 & 1.93 & 2.02 & 1.89 & 2.02 & 2.01 & 0.03 & 0.85 & 0.53 & 0.82 & 0.10 & 0.21 \\
\hline & & 5.04 & 5.19 & 4.76 & 5.29 & 5.19 & & 0.51 & 0.36 & 0.99 & 0.19 & 0.23 \\
\hline Liver/HC & & 2.07 & 2.02 & 2.00 & 2.09 & 2.04 & 0.04 & 0.91 & 0.36 & 0.79 & 0.59 & 0.13 \\
\hline $\mathrm{PH}(\mathrm{kg})$ & 1.8 & 11.1 & 12.3 & 9.8 & 12.4 & 12.6 & 0.40 & 0.01 & 0.26 & 0.79 & $0.03^{(12)}$ & 0.03 \\
\hline & & 4.58 & 4.75 & 4.06 & 4.87 & 4.90 & & 0.24 & 0.19 & 0.70 & 0.06 & 0.07 \\
\hline Forequarte & 90.3 & 88.3 & 93.2 & 83.2 & 93.2 & 93.5 & 2.00 & 0.00 & 0.09 & 0.90 & $0.02^{(13)}$ & 0.07 \\
\hline & & 37.1 & 37.1 & 35.8 & 37.7 & 37.5 & 0 & 0.11 & 0.11 & 0.64 & 0.06 & 0.13 \\
\hline & & 34.2 & 35.6 & 34.0 & 36.2 & 35.3 & 0.75 & 0.86 & 0.93 & 0.89 & 0.52 & 0.36 \\
\hline Spare & & 14.4 & 14.6 & 14.1 & 14.2 & 14.7 & .14 & 0.55 & 0.51 & 0.97 & 0.34 & 0.60 \\
\hline & & 116 & 121 & 115 & 118 & 120 & & 0.56 & 0.84 & 0.80 & 0.27 & 0.90 \\
\hline 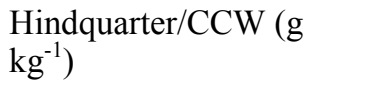 & 48.6 & 48.6 & 48.7 & 49.6 & 47.7 & 48.3 & 0.24 & 0.18 & 0.19 & 0.65 & 0.14 & 0.06 \\
\hline & & 74.7 & 78.6 & 74.0 & 77.3 & 68.8 & 1.24 & 0.14 & 0.86 & 0.12 & 0.22 & 0.09 \\
\hline $\begin{array}{l}\mathrm{LM} \text { area/HCW }(\mathrm{cm} \\
\mathrm{kg})\end{array}$ & 30.1 & 30.5 & 31.0 & 31.1 & 30.7 & 27.3 & 0.63 & 0.24 & 0.73 & 0.09 & 0.08 & 0.31 \\
\hline & & 3.27 & 3.45 & 3.46 & 4.87 & 3.05 & 0.27 & 0.23 & 0.82 & 0.64 & 0.66 & 0.14 \\
\hline & 1.46 & 1.35 & 1.37 & 1.45 & 1.90 & 1.22 & 0.10 & 0.25 & 0.77 & 0.66 & 0.53 & 0.15 \\
\hline & 51.8 & 52.1 & 52.2 & 52.3 & 51.5 & 51.1 & 0.17 & 0.39 & 0.61 & 0.34 & 0.65 & 0.63 \\
\hline Cutability (kg) & 128 & 127 & 132 & 124 & 129 & 129 & 2.30 & 0.25 & 0.49 & 0.43 & 0.26 & 0.44 \\
\hline
\end{tabular}

$3 \mathrm{SOB}$ and $5 \mathrm{SOB}=$ diets with 3 and $5 \%$ ether extract and soybean by-product as lipid source; $3 \mathrm{CSB}, 4 \mathrm{CSB}$ and $5 \mathrm{CSB}=$ diets with 3, 4 and 5\% ether extract and cottonseed by-product as lipid source, respectively.

${ }^{++} \mathrm{SEM}=$ standard error of the mean, $\mathrm{n}=40$.

${ }^{+++} \mathrm{C} 1=3 \mathrm{SOB}$ vs $3 \mathrm{CSB} ; \mathrm{C} 2=5 \mathrm{SOB}$ vs $5 \mathrm{CSB}$; $\mathrm{C} 3=$ linear effect of CBS inclusion; $\mathrm{C} 4$ = quadratic effect of CBS inclusion, contrasts tested by Scheffé's test.

$\mathrm{HCW}=$ hot carcass weight; $\mathrm{CCW}=$ cold carcass weight; $\mathrm{BW}=$ body weight; $\mathrm{KPH}=$ kidney, pelvic and heart fat; $\mathrm{LM}$ area $=M$. longissumus area; $\mathrm{SBF}=$ subcutaneous fat thickness.

$$
\mathrm{KPH}, \mathrm{kg}=1.3+0.02 \times \text { Initial BW }+0.7 \times \mathrm{EE} \text { of the diet with } \mathrm{CSB}(\mathrm{R} 2=0.20 ; P=0.08)
$$

Forequarter, $\mathrm{kg}=-7.76+0.26 \times$ Initial $\mathrm{BW}+3.59 \times \mathrm{EE}$ of the diet with $\mathrm{CSB}\left(\mathrm{R}^{2}=0.72 ; P=0.01\right)$

According to the recommendations of Luchiari Filho (2000) to achieve a good yield of the cuts, the value of the LM area should be $29 \mathrm{~cm} / 100 \mathrm{~kg}$ of HCW and fat cover should be within the range from 2 to $2.5 \mathrm{~mm} / 100 \mathrm{~kg}$ of $\mathrm{HCW}$. The values observed in this study are above the recommended ones for LM area $(30.1 \pm 0.63 \mathrm{~cm} / 100 \mathrm{~kg}$ of $\mathrm{HCW})$ and quite below for the subcutaneous fat $(1.4 \pm 0.1 \mathrm{~mm} / 100 \mathrm{~kg}$ of $\mathrm{HCW})$.

In the description of the normal curve of growth of cattle made by Owens, Gill, Secrist, and Coleman (1995) the muscle growth, strong at puberty, tends to slow down with age and is followed by fat deposition (first KPH, then subcutaneous and, finally, marbling). Thus, the substantial percentage of KPH in relation to cold carcass weight observed in this study is related to the fact that these animals were slaughtered after the phase of fast muscle growth, stimulated mainly by the high levels of protein in the diets (Table 1) and after the deposition of KPH, but before the main period for subcutaneous fat deposition. Nevertheless, on average, $3.62 \pm 0.27 \mathrm{~mm}$ of subcutaneous fat thickness was found. In addition, in all treatments, the values of the subcutaneous fat thickness fat were above 
the minimal threshold of $3 \mathrm{~mm}$ required by the Brazilian meat industry, in contrast with the observations made by Duarte et al. (2011), who found no averages greater than $3 \mathrm{~mm}$ in cattle raised in pasture with more than 8 incisors teeth (about 48 months of age), this finding further demonstrates the potential use of feedlot to improve carcass fat finishing.

In general, the average $\mathrm{HCW}$ was $250.4 \pm 4.74 \mathrm{~kg}$ and the length was $125 \pm 0.88 \mathrm{~cm}$, parameters that were close to the $234.3 \mathrm{~kg}$ and $130 \mathrm{~cm}$ reported by Maggioni, Marques and Rotta (2010) for non-castrated Nellore animals. In addition, the values of $55.4 \pm 0.22 \%$ for HCW/Final BW, $37.0 \pm 0.27 \%$ for forequarter/HCW, $14.4 \pm 0.14 \%$ for spare ribs/HCW and $48.6 \pm 0.24 \%$ for hindquarter/HCW found in this work were close to those reported by Leme et al. (2000) for non-castrated Nellore cattle, that found in same traits: 53.7, 40.6, 12.6 and 46.8\%, respectively; and by Zorzi et al. (2013), who evaluated the effect of residual feed intake in Nellore bulls of similar pedigree to those animals used in this study and found a proportion of forequarter, spare ribs and hindquarter, of 41.2, 12.8 and 46.0 , respectively. In terms of cutability proportion, the overall mean was $51.8 \%$ cut yields in $\mathrm{HCW}$, a value similar to the $50.5 \%$ reported by Larraín et al. (2009).

\section{Conclusion}

Like SOB, the CSB use does not alter the final body weight, weight gain, carcass traits and the ingestive behaviour of animals. However, the use of CSB in diets with high fat raises the dry matter intake, therefore reducing feed efficiency, but ultimately providing a lower gain cost, because CSB is a cheap ingredient.

\section{Acknowledgements}

We thank Fundação de Amparo à Pesquisa do Estado de São Paulo for funding this study and Instituto de Zootecnia for providing the animals.

\section{Reference}

Aferri, G., Leme, P. R., Silva S. L., Putrino, S. M., \& Pereira, A. S. C. (2005). Performance and carcass characteristics of steers fed different fat sources. Brazilian Journal of Animal Science, 34, 1651-1658. http://dx.doi.org/10.1590/S1516-35982005000500027

Alves, A. F., Zervoudakis, J. T., Zervoudakis, L. K. H., CabralL. S., Leonel, F. P., \& Paula N. F. (2010). Replacing soybean meal with high energy cottonseed meal in diets for dairy yielding cows: intake, nutrient digestibility, nitrogen efficiency and milk yield. Brazilian Journal of Animal Science, 39, 532-540.http://dx.doi.org/10.1590/S1516-35982010000300012

Association Official Analytic Chemical. (2007). Official methods of analysis of AOAC international: current through revision (18th ed.). Gaithersburg, MD: Association Official Analytic Chemical.

Beauchemin, K. A., \& Yang, W. Z. (2005). Effects of physically effective fiber on intake, chewing activity, and ruminal acidosis for dairy cows fed diets based on corn silage. Journal of Dairy Science, 88, 2117-2129.http://dx.doi.org/10.3168/jds.S0022-0302(05)72888-5

Berger, L., \& Singh, V. (2010). Changes and evolution of corn coproducts for beef cattle. Journal of Animal Science, 88, E143-E150. http://dx.doi.org/10.2527/jas.2009-2526

Bonilha, S. F. M., Tedeschi, L. O., Packer, I. U., Razook, A. G., Alleoni, G. F., Nardon, R. F., \& Resende, F. D. (2008). Evaluation of carcass characteristics of Bosindicus and tropically adapted Bostaurus breeds selected for postweaning weight. Journal of Animal Science, 86, 1770-1780. http://dx.doi.org/10.2527/jas.2007-0507

Chizzotti, M. L., Valadares Filho, S. C., Leão, M. I., Valadares, R. F. D., Chizzotti, F. H. M., Magalhães, K. A., \& Marcondes, M. I. (2005). Partial replacement of elephantgrass silage with cottonseed hulls. 1. Intake, degradability, and apparent ruminal, intestinal, and total tract digestibilities in steers. Brazilian Journal of Animal Science, 34, 2093-2102. http://dx.doi.org/10.1590/S1516-35982005000600035

Costa, Q. P. B., Wechsler, F. S., Costa, D. P. B., Polizel Neto, A., Roça, R. O., \& Brito, T. P. (2011). Performance and carcass traits of steers fed diets containing whole cottonseed. Arquivo Brasileiro de Medicina Veterinária e Zootecnia, 63,729-735. http://dx.doi.org/10.1590/S0102-09352011000300026

Cranston, J. J., Rivera, J. D., Galyean, M. L., Brashears, M. M., Brooks, J. C., Markham, C. E., Mcbeth, L. J., \& Krehbiel, C. R. (2006). Effects of feeding whole cottonseed and cottonseed products on performance and carcass characteristics of finishing beef cattle. Journal of Animal Science, 84, 2186-2199. http://dx.doi.org/10.2527/jas.2005-669

Cross, H. R., Carpenter, Z. L., \& Smith, G. C. (1973). Equations for estimating boneless retail cut yields from beef carcasses. Journal of Animal Science, 37, 1267-1272. 
Detmann, E., Queiroz, A. C., Cecon, P. R., Zervoudakis, J. T., Paulino, M. F., Valadares Filho, S. C., ... Lana, R. P. (2003). Neutral detergent fiber intake by feedlot cattle.Brazilian Journal of Animal Science, 32, 1763-1777, Supplement 1. http://dx.doi.org/10.1590/S1516-35982003000700027

Duarte, M. S., Paulino, P. V. R., Fonseca, M. A., Diniz, L. L., Cavali, J., Serão, N. V. L., ... Cox, R. B. (2011). Influence of dental carcass maturity on carcass traits and meat quality of Nellore bulls. Meat Science, 88 , 441-446. http://dx.doi.org/10.1016/j.meatsci.2011.01.024

Felton, E. E. D., \& Kerley, M. S. (2004a). Performance and carcass quality of steers fed whole raw soybeans at increasing inclusion levels. Journal of Animal Science, 82, 725-732.

Felton, E. E. D., \& Kerley, M. S. (2004b). Performance and carcass quality of steers fed different sources of dietary fat. Journal of Animal Science, 82, 1794-1805.

Fox, D. G., Sniffen, C. J., O'Connor, J. D., Russell, J. B., \& Van Soest, P. J. (1992). A net carbohydrate and protein system for evaluating cattle diets: III. Cattle requirements and diet adequacy. Journal of Animal Science, 70, 3578-3596.

Galyean, M. L., \& Defoor, P. J. (2003). Effects of roughage source and level on intake by feedlot cattle. Journal of Animal Science, 81, E8-E16.

Gunn, P. J., Weaver, A. D., Lemenager, R. P., Gerrard, D. E., Claeys, M. C., \& Lake, S. L. (2009). Effects of dietary fat and crude protein on feedlot performance, carcass distillers grains with solubles characteristics, and meat quality in finishing steers fed differing levels of dried. Journal of Animal Science, 87, 2882-2890. http://dx.doi.org/10.2527/jas.2008-1521

Ítavo, L. C. V., Valadares Filho, S. C., Silva, F. F., Valadares, R. F. D., \& Cecon, P. R. (2002). Concentrate and crude protein levels in growing nelorebulls diets: Intake and digestibility. Brazilian Journal of Animal Science, 31, 1033-1041. http://dx.doi.org/10.1590/S1516-35982002000400028

Kazama, R., Zeoula, L. M., Prado, I. N., Silva, D. C., Ducatti, T., \& Matsushita, M. (2008). Quantitative and qualitative carcass characteristics of heifers fed different energy sources on a cottonseed hulls and soybean hulls based diet. Brazilian Journal of Animal Science, 37, 350-357. http://dx.doi.org/10.1590/S1516-35982008000200023

Larraín, R. E., Schaefer, D. M., Arp, S. C., Claus, J. R., \& Reed, J. D. (2009). Finishing steers with diets based on corn, high-tannin sorghum, or a mix of both: Feedlot performance, carcass characteristics, and beef sensory attributes.Journal of Animal Science, 87, 2089-2095. http://dx.doi.org/10.2527/jas.2007-0433

Leme, P. R., Boin, C., Margarido,R. C. C., Tedeschi, L. O., Hausknecht, J. C. O. V., Alleoni, G. F., \& Luchiari Filho, A. (2000). Growth performance in feedlot and carcass characteristics of beef cattle from several crossbreds slaughtered in three body weight ranges. Brazilian Journal of Animal Science, 29, 2347-2353, Supplement 2.

Lofgreen, G. P. (1965). Net energy of fat and molasses for beef heifers with observations on the method for net energy determination. Journal of Animal Science, 24, 480-487.

Luchiari Filho, A. (2000). Pecuária da carne bovina. São Paulo: SP, LinBife.

Machado Neto, O. R., Ladeira, M. M., Goncalves, T. M., Lopes, L. S., Oliveira, D. M., \& Bassi, M. S. (2010). Feed intake and prediction assessments using the NRC, CNCPS and BR-CORTE systems in Nellore and Red Norte steers finished in feedlot. Brazilian Journal of Animal Science, 39, 394-401. http://dx.doi.org/10.1590/S1516-35982010000200024

Magalhães, K. A., Valadares Filho, S. C., Paulino, M. F., Valadares, R. F. D., Paulino, P. V. R., Chizzotti, M. L., ... Moraes, K. A. K. (2005). Effects of feeding different levels of cottonseed hulls on production and carcass physical composition and traits of feedlot steers. Brazilian Journal of Animal Science, 34, 2466-2474. http://dx.doi.org/10.1590/S1516-35982005000700035

Maggioni, D., Marques, J. A., \& Rotta, P. P. (2010). Animal performance and meat quality of crossbred young bulls.Livestock Science, 127, 176-182. http://dx.doi.org/10.1016/jlivsci.2009.09.006

Meneghetti, S. M. P., Meneghetti, M. R., Wolf, C. R., Silva, E. C., Lima, G. E. S., Coimbra, M. A., ... Carvalho, S. H. V. (2006). Ethanolysis of castor and cottonseed oil: a systematic study using classical catalysts. Journal of the American Oil Chemists' Society, 83, 819-822. http://dx.doi.org/10.1007/s11746-006-5020-3 
Messana, J. D., Berchielli, T. T., \& Arcuri, P. B. (2010). Effects of dry sugar cane yeast on the diet intake, digestibility and bovine rumen microbial populations. Livestock Science, 129, 208-212. http://dx.doi.org/10.1016/jlivsci.2010.02.001

Millen, D. D., Pacheco, R. D. L., Arrigoni, M. D. B., Galyean, M. L., \& Vasconcelos, J. T. (2009). A snapshot of management practices and nutritional recommendations used by feedlot nutritionists in Brazil. Journal of Animal Science, 87, 3427-3439. http://dx.doi.org/10.2527/jas.2009-1880

Moore, J. A., Poore, M. H., \& Swingle, R. S. (1990). Influence of roughage source on kinetics of digestion and passage, and on calculated extents of ruminal digestion in beef steers fed $65 \%$ concentrate diets. Brazilian Journal of Animal Science, 68, 3412-3420.

Owens, F. N., Gill, D. R., Secrist, D. S., \& Coleman, S. W. (1995).Review of some aspects of growth and development of feedlot cattle. Journal of Animal Science, 73, 3152-3172.

Pina, D. S., Valadares Filho, S. C., Valadares, R. F. D., Detmann, E., Campos, J. M. S., Fonseca, M. A., ,.. Oliveira, A. S. (2006). Estimation of microbial protein synthesis and urea nitrogen metabolism in lactating dairy cows fed diets supplemented with different protein sources. Brazilian Journal of Animal Science, 35, 1552-1559. http://dx.doi.org/10.1590/S1516-35982006000500038

Statistical Analysis System. (2002). User's guide, Release 9.0 Cary, NC: SAS Institute Incorporation.

Stelzleni, A. M., Froetschel, M. A., \& Pringle, T. D. (2013). Effects of feeding extruded full-fat cottonseed pellets in place of tallow as a fat source for finishing heifers on feedlot performance, carcass characteristics, sensory traits, display color, and fatty acid profiles. Journal of Animal Science, 91, 4510-4520. http://dx.doi.org/10.2527/jas.2013-6414

Valadares Filho S. C., Rocha Junior, V. R., \& Cappelle, E. R. (2006). Tabelasbrasileiras de composição de alimentosparabovinos (2nd ed.). Viçosa: MG, Editora UFV.

Van Soest, P. J., Robertson, J. B., \& Lewis, B. A. (1991).Methods for dietary fiber, neutral detergent fiber, and nonstarch polysaccharides in relation to animal nutrition. Journal of Dairy Science, 74, 3583-3597. http://dx.doi.org/10.3168/jds.S0022-0302(91)78551-2

Vander Pol, K. J., Luebbe, M. K., Crawford, G. I., Erickson, G. E., \& Klopfenstein, T. J. (2009). Performance and digestibility characteristics of finishing diets containing distillers grains, composites of corn processing coproducts, or supplemental corn oil. Journal of Animal Science, 87, 639-652. http://dx.doi.org/10.2527/jas.2008-1036

Vasconcelos, J. T., \& Galyean, M. L. (2007). Nutritional recommendations of feedlot consulting nutritionists: the 2007. Texas Tech University survey. Journal of Animal Science, 85, 2772-2781. http://dx.doi.org/10.2527/jas.2007-0261

Winterholler, S. J., Lalman, D. L., Hudson, M. D., \& Goad, C. L. (2009). Supplemental energy and extruded-expelled cottonseed meal as a supplemental protein source for beef cows consuming low-quality forage. Journal of Animal Science, 87, 3003-3012. http://dx.doi.org/10.2527/jas.2008-1605

Wogar, G. S. I., \& Ayuk, A. A. (2012). By-products as protein source for lactating grasscutters. Journal of Agricultural Science, 4, 148-153. http://dx.doi.org/10.5539/jas.v4n7p148

Zinn, R. A. (1989a). Influence of level and source of dietary fat on its comparative feeding value in finishing diets for steers: Feedlot cattle growth and performance. Journal of Animal Science, 67, 1029-1037.

Zinn, R. A. (1989b). Influence of level and source of dietary fat on its comparative feeding value in finishing diets for feedlot steers: metabolism. Journal of Animal Science, 67, 1038-1049.

Zorzi, K., Bonilha, S. F. M., Queiroz, A. C., Branco, R. H., Sobrinho, T. L., \& Duarte, M. S. (2013).Meat quality of young Nellore bulls with low and high residual feed intake. Meat Science, 93, 593-599. http://dx.doi.org/10.1016/j.meatsci.2012.11.030

\section{Copyrights}

Copyright for this article is retained by the author(s), with first publication rights granted to the journal.

This is an open-access article distributed under the terms and conditions of the Creative Commons Attribution license (http://creativecommons.org/licenses/by/3.0/). 